\title{
Impoundment impact on populations of facultative riverine fish
}

\author{
A. Kruk, T. Penczak
}

Department of Ecology and Vertebrate Zoology, University of Lodz, 12/16 Banacha Str., 90-237 Lodz, Poland. E-mail: krunio@ biol.uni.lodz.pl

\begin{abstract}
A long-term study (1985-1999) conducted at backwater and tailwater sites of a large reservoir located in the middle course of the $808 \mathrm{~km}$ long Warta River (Poland), showed that not only obligatory riverine species suffer from the effect of the dam. Facultative riverine eel, burbot, wels and pike considerably decreased in number and standing crop, including their apparent absence in some years following the damming. Nevertheless, median densities of perch and roach, two generalists thriving in European regulated rivers, increased from tens and hundreds, respectively, to thousands per hectare. Significant increases in density were also recorded for other four species: zander, ruffe, bream and silver bream. Thus, the reaction of facultative riverine fish, often supposed to be resistant to aquatic habitat deterioration, is diverse with respect to impoundment. Apart from the migratory eel, which have not been caught at the backwater site for the last 8 years, all the remaining significant temporal changes were recorded at the tailwater site. Out of habitat flexibility coefficients relating to refuge, feeding and spawning, only the latter considerably differed between the successful and unsuccessful species after impoundment, which testifies to the critical role of spawning flexibility in a human-modified environment.
\end{abstract}

Keywords : dam effect, river regulation, eurytopic fish, migratory fish, spawning flexibility.

\section{Introduction}

One classification of fish species relates to the ability to complete their life cycle dependant on access to the riverine environments. Obligatory riverine species spawn only in the river corridor, while facultative (non obligatory) riverine species can realize their life history strategy in both stagnant and flowing waters (Holden 1979, Schiemer \& Waidbacher 1992).

These two groups have been considered to react in a $\mathrm{d}$ i fferent way to the construction of dams, whose effects on aquatic habitats and fish populations were evaluated as catastrophic (Petts 1984, Martinez et al. 1994, Penczak 1999). Almost all obligatory riverine fish species suffer severely from dam construction without effective fish ladders, including the local extirpation of many of them (Penczak et al. 1998, Penczak \& Kruk 2000). The main reason for this is disruption of river continuum (Ward \& Stanford 1983). Dam construction often leads to changes in flow regime, amount and composition of suspended solids, alternation of physical and chemical water parameters, reduction in number of microhabitats, blocking of migration routes, changes in abundance of food and altered recruitment of 0+ fish (Welcomme 1985). When other stressors accompanying damming (bank revetments, removal of bankside vegetation, wing dikes construction along the eroded bank) and construction of a hydropower station (pulse releases and changes in thermic regime) are considered, then one comes against a difficulty of distinguishing them from the sole effect of impoundment (Northcote et al. 1985).

Facultative riverine species, in contrast, are generally regarded as more resistant to alternations in water flow and river channel, and many papers present examples of their densities positively related to habitat change (e.g. Adámek et al. 1985, Oberdorff \& Hughes 1992, Penczak 1994, Wolter \& Vilcinskas 1997, Penczak \& Kruk 2000, Kruk et al. 2001, Wolter 2001, Penczak et al. 2002). On the other hand, some of our 
long-term studies (Penczak 1992, 1999, Penczak et al. 1998, Glowacki \& Penczak 2000, Kruk et al. 2001) indicate that certain facultative riverine species may suffer impacts from the Jeziorsko Reservoir construction.

Thus, the object of this study is to evaluate the status of facultative riverine fish populations in the dammed Warta River (no fish ladder) over 12 years after its impoundment.

\section{Material and methods}

The following facultative riverine native species, recorded more often than sporadically and used to be harvested by anglers, were studied: eel Anguilla an guilla (L.), burbot Lota lota (L.), wels Si l u rus glanis L., pike Esox lucius L., zander Stizostedion lucioperca (L.), ruffe Gymnocephalus cernuus (L.), perch Perca fluviatilis L., roach Rutilus rutilus (L.), bream Abramis brama (L.) and silver bream Blicca bjoerkna (L.) They were selected out of 31 species recorded altogether (Penczak et al. 1991, 1994, 1998, Penczak in press).

The dam sluices of the Jeziorsko Reservoir (middle course of the $808 \mathrm{~km}$ long Warta River), lacking fish pass, were closed for the first time in spring 1986, but because of construction errors they were completely re-opened in 1987 and the reservoir was emptied. It was filled in again in 1988, hence we treated data collected in the years 1985-87 (6 sampling occasions) as from the pre-impoundment period, and those obtained in 1988-99 (21 sampling occasions) as from the postimpoundment period. In August 1994 a hydropower station started operating.

Fishes in the Warta River were quantitatively sampled every year from 1985 to 1999 , usually in late April and October, at two sites: AB and CD. Site AB (area $20080 \mathrm{~m}^{2}$ ) was located ca. $2 \mathrm{~km}$ upstream of the r e s e r v o i r's backwater. Site CD (area $33050 \mathrm{~m}^{2}$ ) was located about $1.5 \mathrm{~km}$ downstream of the dam (Fig. 1). The mean annual Warta discharge during this period was $36.7 \mathrm{~m}^{3} \mathrm{~s}^{-1}\left(33.1-48.4 \mathrm{~m}^{3} \mathrm{~s}^{-1}\right)$. The mean current velocity was $0.6-0.9 \mathrm{~m} \mathrm{~s}^{-1}$ dependant on the season
(Penczak et al. 1996). Sites morphological characteristics are presented in table 1 . Physico-chemical water parameters for the study period (yearly mean and range) and description of pollutions sources (mainly domestic) are also available for the study period: 1985-89 (Galicka et al. 1991), 1990-92 (Penczak et al. 1994), 1993-95 (Penczak et al. 1998) and 1996-99 (Penczak in press). Since beginning of 1990s water quality in Polish rivers started successively improving because of bankruptcy of many chemical and heavy industry plants and coal mines. The conductivity, which is a general measure of amount of dissolved salts, after 1994 at site $\mathrm{AB}$ was in the range $212-281 \mu \mathrm{S} . \mathrm{cm}^{-1}$, and at CD 209-270 $\mu \mathrm{S} . c m^{-1}$, but before was about 100 $\mu \mathrm{S} . \mathrm{cm}^{-1}$ higher. At AB both banks were grown mainly by willows (Salix sp.) and rarely by Alnus sp. At CD till 1993 there were little submerged macrophytes. Since summer 1994 large patches of Potamogeton filifor mis Pers. and small ones of P. lucens L. covered with long filaments of Cladophora glomerata (L.) Kutz have been observed extending over $20 \%$ of bed in transverse section (Grzybkowska \& Dukowska 2001). Detailed descriptions of sites, including bathymetric maps, are presented in earlier papers (Penczak 1992, Penczak et al. 1998).

Population densities on every occasion were obtained from three successive electrofishing surveys carried out simultaneously $(<36 \mathrm{~h})$ at both sites at constant unit of effort (CPUE) from a boat at the right bank while drifting with the water current, and then repeated on the left bank of the river, using two anodedipnets with a pulsed D.C. output of 230 V and 3-10 A. Fishing in the middle river zone at each of the sites produced only few fish of 2-3 pelagic species: dace Leuciscus leuciscus (L.), bleak Alburnus alburnus (L.) and roach (Penczak \& Romero 1990). The Zippin (1956) triple catch removal method was used to estimate population density on each sampling occasion. Validity of this method was testified by Penczak and Romero (1990) in the first years of collecting samples (1985, 1986).

Table 1. Characteristics of sites $\mathrm{AB}$ and $\mathrm{CD}(\mathrm{s}=$ sand, $\mathrm{g}=$ gravel, $\mathrm{st}=$ stones, $\mathrm{m}=$ mud).

\begin{tabular}{|c|c|c|c|c|c|c|c|c|c|}
\hline \multirow{2}{*}{ A: } & \multirow[t]{2}{*}{ Len'thing (m) } & \multirow[t]{2}{*}{ Preth } & \multicolumn{2}{|c|}{ Death (nin) } & \multirow{2}{*}{ Akg (m) } & \multicolumn{4}{|c|}{ 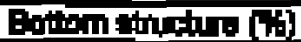 } \\
\hline & & & $m$ & mx & & 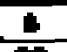 & $\pi$ & + & In \\
\hline $\mathbf{A B}$ & 450 & $40+5$ & 1.5 & 26 & 2000 & 60 & 10 & 5 & $\mathbf{J}$ \\
\hline 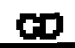 & By & $46-\pi$ & 14 & 2.0 & 3405 & 6 & E & $\mathrm{E}$ & 7 \\
\hline
\end{tabular}




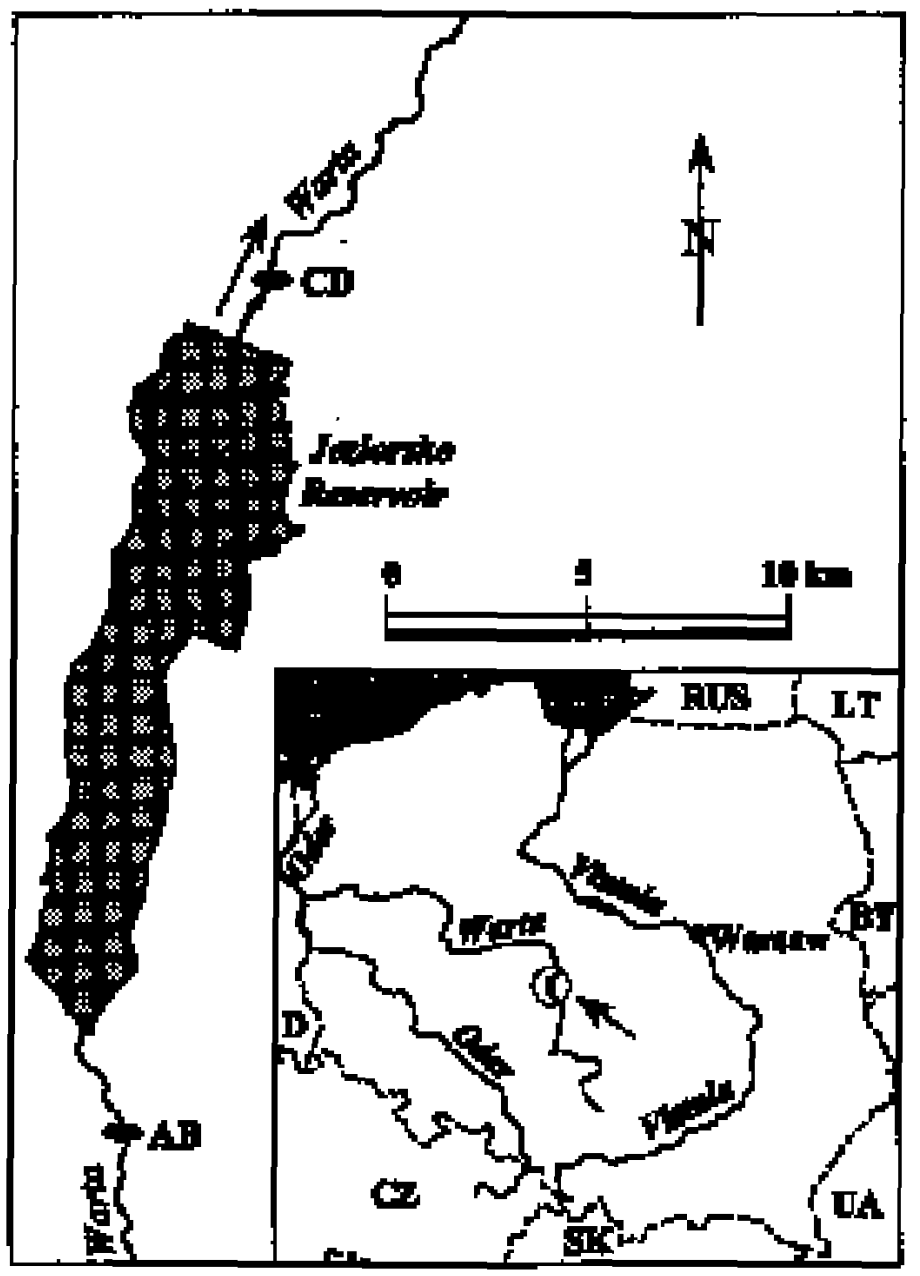

Fig. 1. Study area with the map of Poland. AB - upstream site, CD - downstream site.

Fluctuations in fish populations were analysed over time and over space. For the temporal comparison firstly we searched for significant changes in facultative riverine species density and standing crop $\left(\mathrm{ha}^{-1}\right)$ at both sites, but the final significance level was determined on the basis of a procedure proposed by StewartOaten et al. (1986) and resting on the assumption that the difference between $\mathrm{AB}$ and $\mathrm{CD}$, in any of these two parameters, could considerably change because of the dam construction. The procedure consists in comparing, with use of the Mann-Whitney $U$ test, the series of the 6 pre-impoundment differences (between simultaneously sampled $\mathrm{AB}$ and $\mathrm{CD}$ ) against the series of the 21 post-impoundment differences (between simul- taneously sampled AB and CD). Such methodology avoids the problems with pseudoreplication and independence of samples (Stewart-Oaten et al. 1986). In the spatial analysis we compared density and standing crop between the backwater (AB) and tailwater (CD) after impoundment, using the Wilcoxon matched pairs test (Zar 1998).

As an undegraded river of similar size which could serve as a reference system was unavailable, the changes in facultative riverine species at $\mathrm{AB}$ and $\mathrm{CD}$ were compared to changes in a 178-km-long section of the upper Warta (upstream of AB) sampled in 1986 at 21 sites (Przybylski et al. 1993) and in 1998 at 19 sites 
(Kruk et al. 2000). The section is the best preserved river fragment (Kruk et al. 2000).

Facultative riverine species for which significant changes were recorded in this study, and rheophils (chub Leuciscus cephalus (L.), dace Leuciscus leucis cus (L.), barbel Barbus barbus (L.), gudgeon Gobio gobio (L.)) studied by Penczak and Kruk (2000) in the Warta River also at $\mathrm{AB}$ and $\mathrm{CD}$, were divided into two groups: 1) those which increased, and 2) those which decreased in numbers at $\mathrm{AB}$ and/or CD after impoundment. Between the two groups coefficients of habitat flexibility (refuge, feeding, spawning), taken from Grandmottet (1983) (table 2), were compared with use of the Mann-Whitney $U$ test (Zar 1998). We could not find coefficients for eel and wels.

\section{Results}

In the study significant differences over time and/or space were recorded for all 10 studied facultative riverine species.

At the AB site the only species showing significant differences over time was eel. Its density dropped after dam construction and since 1992 no eels have been caught there (Fig. 2a, 3a).

Species showing reductions in estimated abundance at the CD site, i.e. downstream of the Jeziorsko Reser- voir dam were: burbot, wels and pike (Fig. 3a). Though only the decrease in density and standing crop for pike was significant, for the two remaining species was also drastic with median values equal 0 in the post-impoundment period. Wels were last recorded at CD in 1989 (Fig. 2a).

Three predatory percids: zander, ruffe and perch increased at CD after impoundment (Fig. 2a, b). Their median density rose from close to 0 up to tens, hundreds and thousands respectively, after damming (Fig. $3 \mathrm{a}, \mathrm{b})$. Changes in standing crop resembled increases in density, although the increase in zander standing crop was insignificant. Perch, in the post-impoundment period, was about 100 times more numerous and became the most dominant, outstripping the other species both in density and standing crop (Fig. 2b).

Impoundment also was followed by increases at CD in population abundance and biomass of three cyprinids: roach, bream and silver bream. Roach, the most dominant species in 1980s, increased in number about five times after damming (Fig. $2 b, 3 b$ ), becoming the second ranked in dominance. Bream increased in abundance by two orders of magnitude (Fig. 3b). For these two species, increase in standing crop was proportionally less than in abundance. Density and standing crop of silver bream increased about six and seven times respectively after impoundment (Fig. 3b).

Table 2. Coefficients of habitat flexibility for different elements of the adult habitats of selected species (Grandmottet 1983). Explanation: low value of a coefficient = narrow range of acceptable habitats, high value of a coefficient $=$ wide range of acceptable habitats. *: Classification for first four species based on Penczak \& Kruk (2000).

\begin{tabular}{|c|c|c|c|c|}
\hline Habitat element & Refuge & Feeding & Spawning & Overall \\
\hline \multicolumn{5}{|c|}{ After impoundment unsuccessful* species } \\
\hline Leuciscus cephalus & 0.43 & 1.00 & 0.55 & 0.62 \\
\hline Leuciscus leuciscus & 0.45 & 1.00 & 0.11 & 0.37 \\
\hline Barbus barbus & 0.12 & 0.11 & 0.06 & 0.09 \\
\hline Gobio gobio & 0.71 & 0.20 & 0.12 & 0.26 \\
\hline Lota lota & 0.08 & 0.72 & 0.13 & 0.19 \\
\hline Esox lucius & 0.05 & 0.78 & 0.03 & 0.12 \\
\hline \multicolumn{5}{|c|}{ After impoundment successful species } \\
\hline $\begin{array}{l}\text { Stizostedion } \\
\text { lucioperca }\end{array}$ & 0.09 & 0.78 & 0.27 & 0.27 \\
\hline $\begin{array}{l}\text { Gymnocephalus } \\
\text { cernuus }\end{array}$ & 0.57 & 0.64 & 0.27 & 0.46 \\
\hline Perca fluviatilis & 0.12 & 0.78 & 0.14 & 0.24 \\
\hline Rutilus rutilus & 0.43 & 0.78 & 0.46 & 0.54 \\
\hline Abramis brama & 0.14 & 0.38 & 0.39 & 0.26 \\
\hline Blicca bjoerkna & 0.27 & 0.31 & 0.28 & 0.29 \\
\hline
\end{tabular}




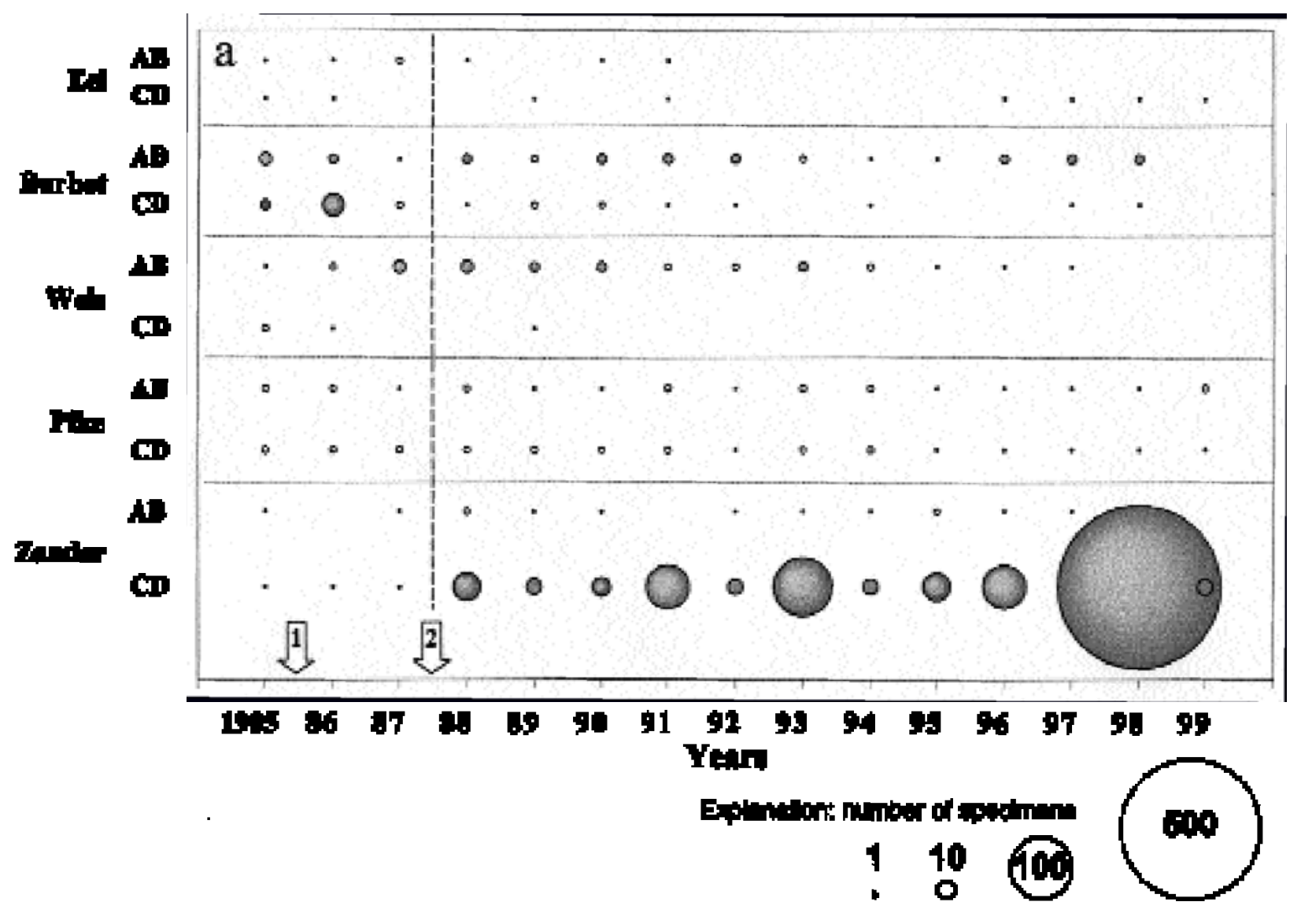

Fig. 2a. Annual mean population densities (specimens ha ${ }^{-1}$ ) of (a) eel, burbot, wels, pike, zander, and (b) ruffe, perch, roach, bream and silver bream, in the Warta River upstream (AB) and downstream (CD) of the Jeziorsko reservoir. Arrows with a number show the first and second terms of dam sluices closing.

In spatial comparison, although lower, eel density and standing crop at $\mathrm{AB}$ were not significantly diff erent from CD (Fig. 4a). Single eels were caught downstream of the dam (CD) up to 1999, while at AB the last time was in 1991 (Fig. 2a).

Burbot density and standing crop declined at CD in comparison to AB (Fig. 2a, 4a), which still looks like a natural river. Wels almost completely disappeared at $\mathrm{CD}$ after the dam construction (Fig. 2a, 4a). For pike, only the decrease in standing crop at CD was significant (Fig. 4a).

After the reservoir construction, the first conspicuous difference between backwater $(\mathrm{AB})$ and tailwater (CD) sites was a significant increase in fish numbers at the CD site (Fig. 2a, b). This was because densities and standing crops of zander, ruffe, perch, roach, bream and silver bream were significantly higher at the tailwater site (Fig. 4a, b). Differences in density for zander, ruffe, perch and bream were over 30 times as high. In each case the difference in standing crop was lower than in density (Fig. 4a, b).

In the reference river section located upstream of $\mathrm{AB}$, significant temporal differences were found only in case of eel and perch (table 3). For most of remaining species little change was recorded.

Out of coefficients of habitat flexibility, only the one relating to spawning considerably differed between the species whose densities declined or increased after impoundment (Fig. 5). Though the interquartile ranges did not overlap, the difference was only close to significance. The other two coefficients assumed similar values. 


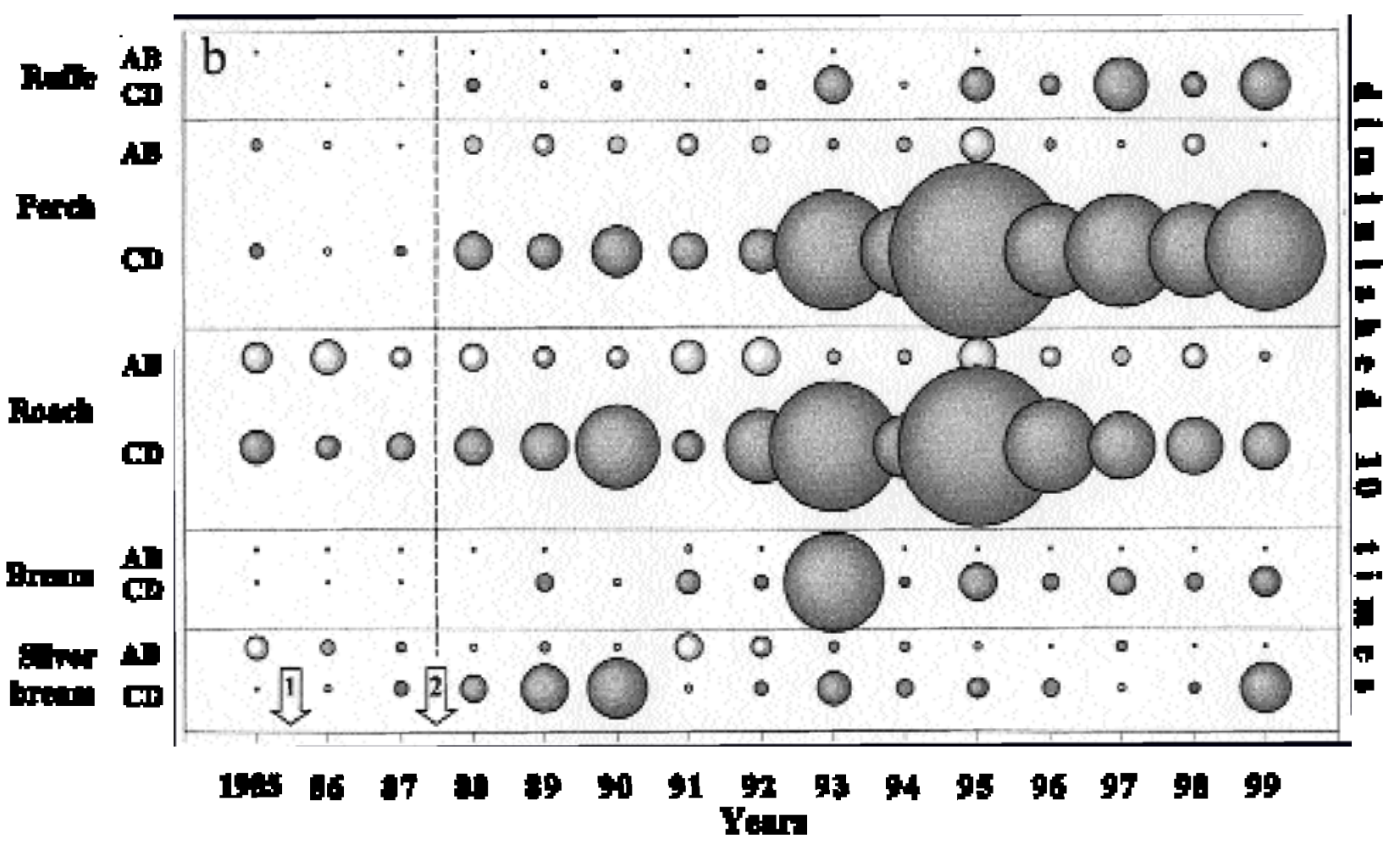

Fig. 2b. Annual mean population densities (specimens ha-1) of (a) eel, burbot, wels, pike, zander, and (b) ruffe, perch, roach, bream and silver bream, in the Warta River upstream (AB) and downstream (CD) of the Jeziorsko reservoir. Arrows with a number show the first and second terms of dam sluices closing.

\section{Discussion}

We know of no European complex studies in which the effects of dams on facultative riverine fish has been statistically analysed. There are some North American studies (Ney \& Mauney 1981, Erman 1986, Koryak \& Hoskin 1994, Travnichek et al. 1995), but the facultative riverine species from that continent are taxonomically different from those in Europe, hence comparisons are difficult.

In our opinion, the time- and space-related changes observed in the abundance of eel, burbot, wels and pike were induced by a combination of several impoundment-related factors: 1) lack of river continuity affecting ichthyofauna both at $\mathrm{AB}$ and $\mathrm{CD}, 2$ ) great hydrological changes in the tailwater reach of the Warta $\mathrm{Ri}$ $\mathrm{v}$ e $\mathrm{r}$, such as pulse releases (within a short time larg e volumes of water released and then discharge reduced even to the point of exposing the river bed) (Penczak et al. 1998), 3) poaching with nets and baskets possible when river bed is uncovered and fish remain in few pools (Penczak et al. 1998), 4) increased eutrophication leading to toxic cyanobacterial blooms (Tarczynska et al. 2001), 5) changes in ecotone structure: protection of bank with fascine and revetment, cutting out of bankside trees and shrubs, wing dikes construction (Penczak et al. 1998).

The above listed factors, except for the first one, affect to a greater extent fish populations downstream of the reservoir (Penczak et al. 1984, Garcia de Jalon et al. 1994, Martinez et al. 1994, Lusk et al. 1995, Rosenb e rg et al. 1997, Ponton \& Vauchel 1998), which is confirmed by the higher number of significant diff erences recorded over time at $\mathrm{CD}$ than at $\mathrm{AB}$ (Fig. 3a, 

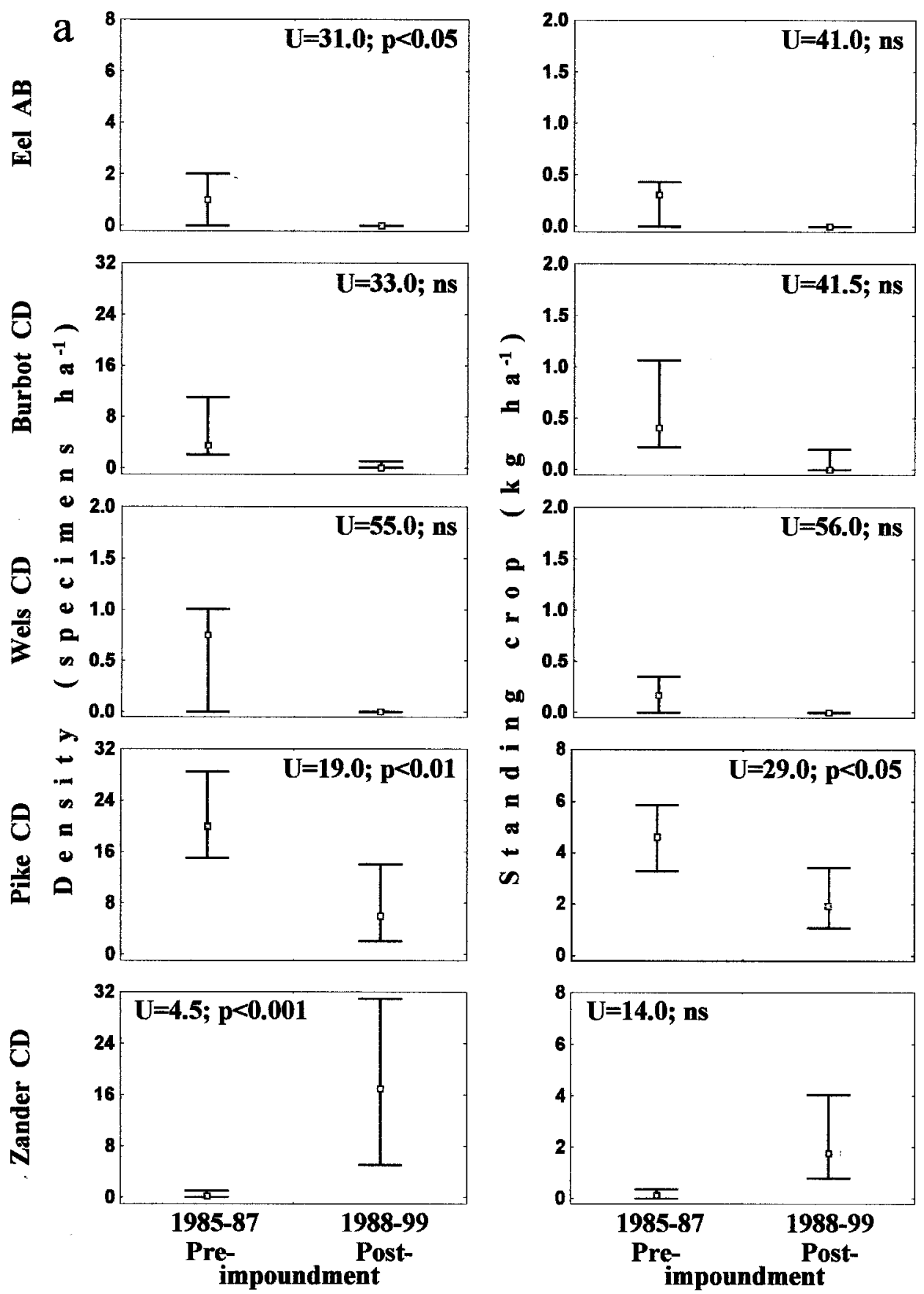

Fig. 3a. Temporal comparisons of densities and standing crops (median and quartiles) of (a) eel at AB, and burbot, wels, pike, zander at $C D$, and (b) ruffe, perch, roach, bream and silver bream at $C D$, in the Warta River, between the pre- and post-impoundment periods (Mann-Whitney U test for changes in differences between simultaneously samples $\mathrm{AB}$ and $\left.\mathrm{CD}, \mathrm{n}_{1985-87}=6, \mathrm{n}_{1988-99}=21\right)$. 

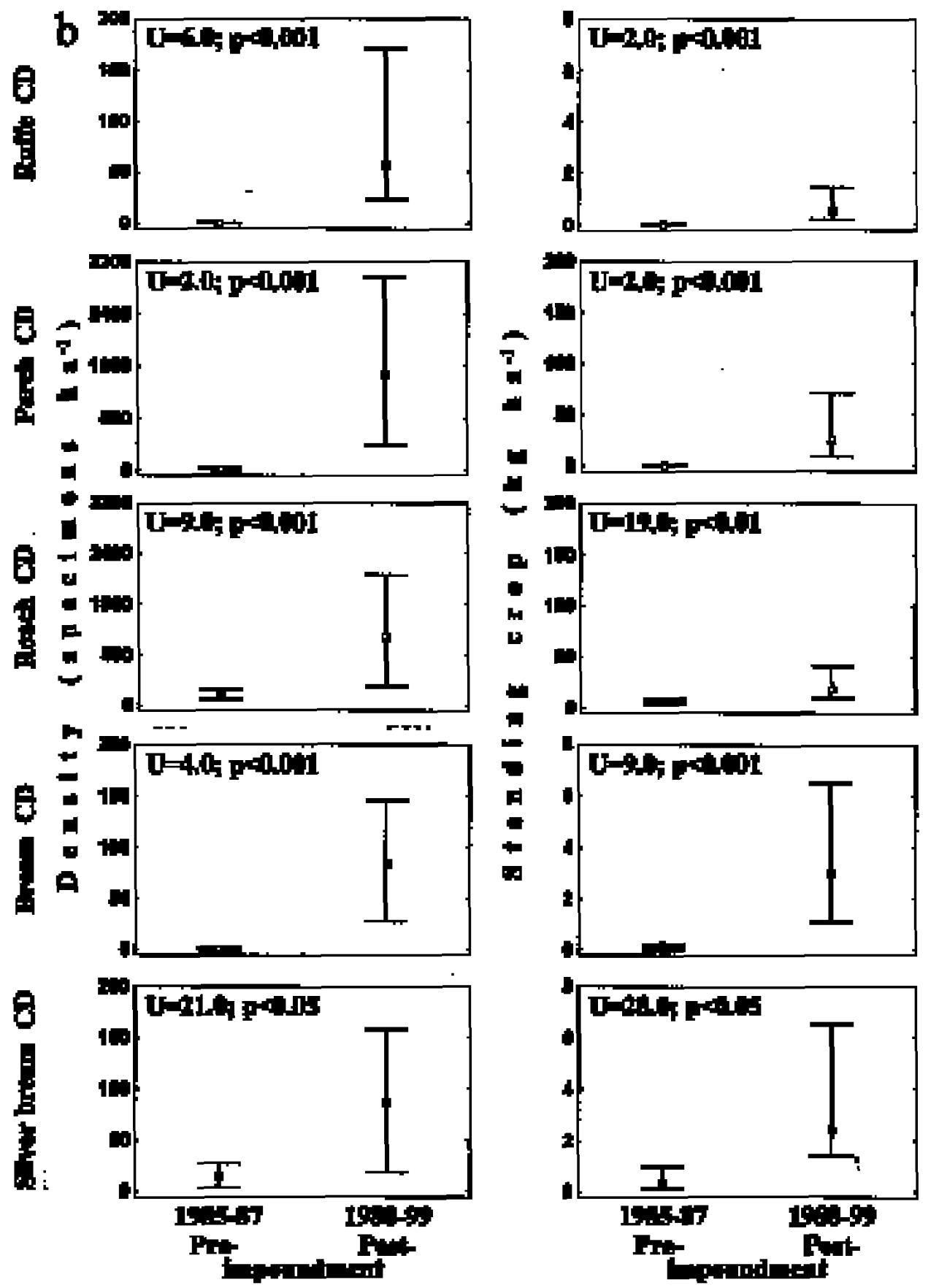

Fig. 3b. Temporal comparisons of densities and standing crops (median and quartiles) of (a) eel at AB, and burbot, wels, pike, zander at $\mathrm{CD}$, and (b) ruffe, perch, roach, bream and silver bream at $\mathrm{CD}$, in the Warta River, between the pre- and post-impoundment periods (Mann-Whitney $\mathrm{U}$ test for changes in differences between simultaneously samples $A B$ and $C D, \mathrm{n}_{1985-87}=6, \mathrm{n}_{1988-99}=21$ ). 

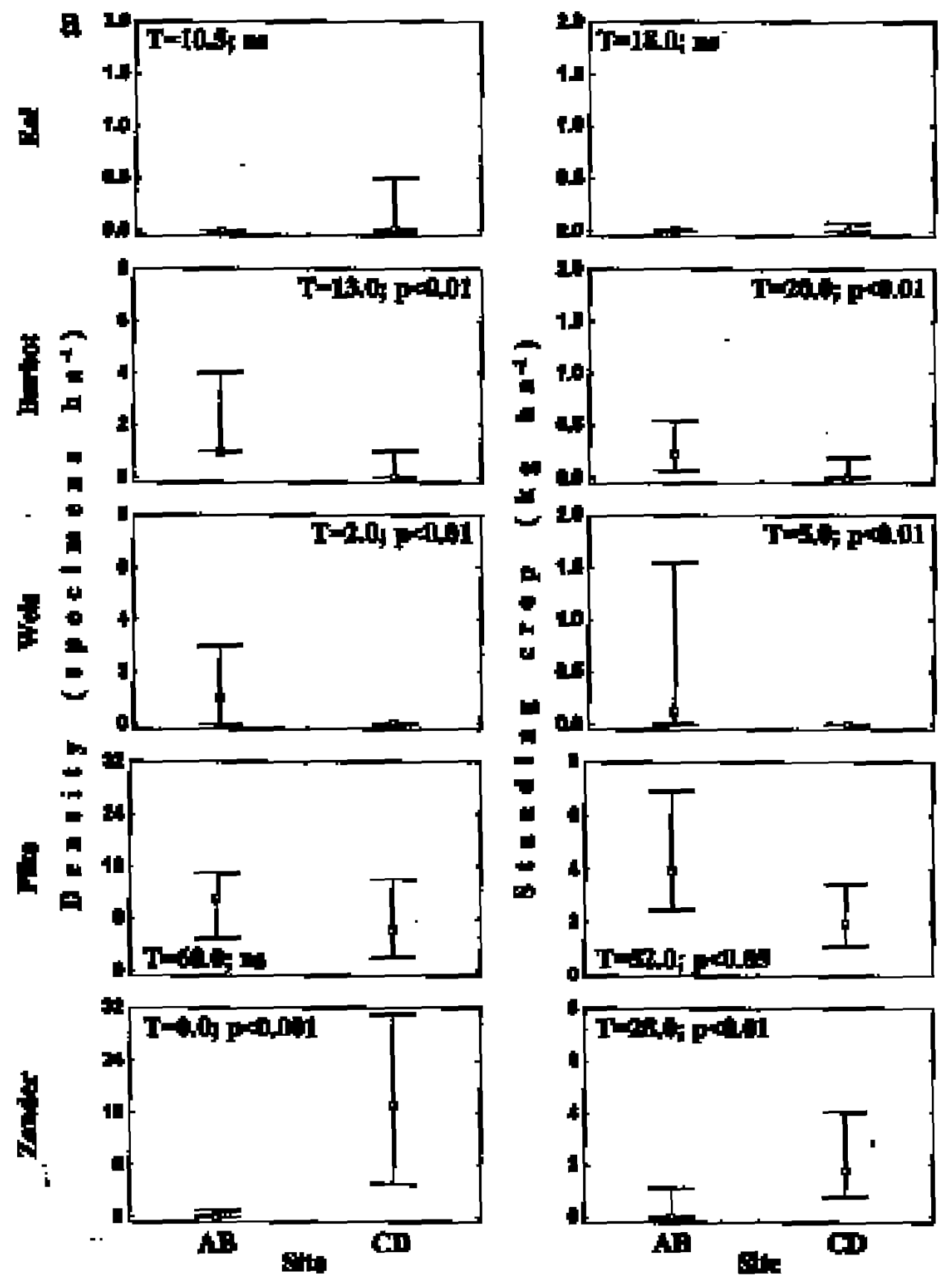

Fig. 4a. Spatial comparisons of densities and standing crops (median and quartiles) of (a) eel, burbot, wels, pike, zander, and (b) ruffe, perch, roach, bream and silver bream, between the backwater (AB) and tailwater (CD) in the Warta River for the post-impoundment period (Wilcoxon matched pairs test, $\mathrm{n}_{\mathrm{AB}}=21, \mathrm{n}_{\mathrm{CD}}=21$ ). 

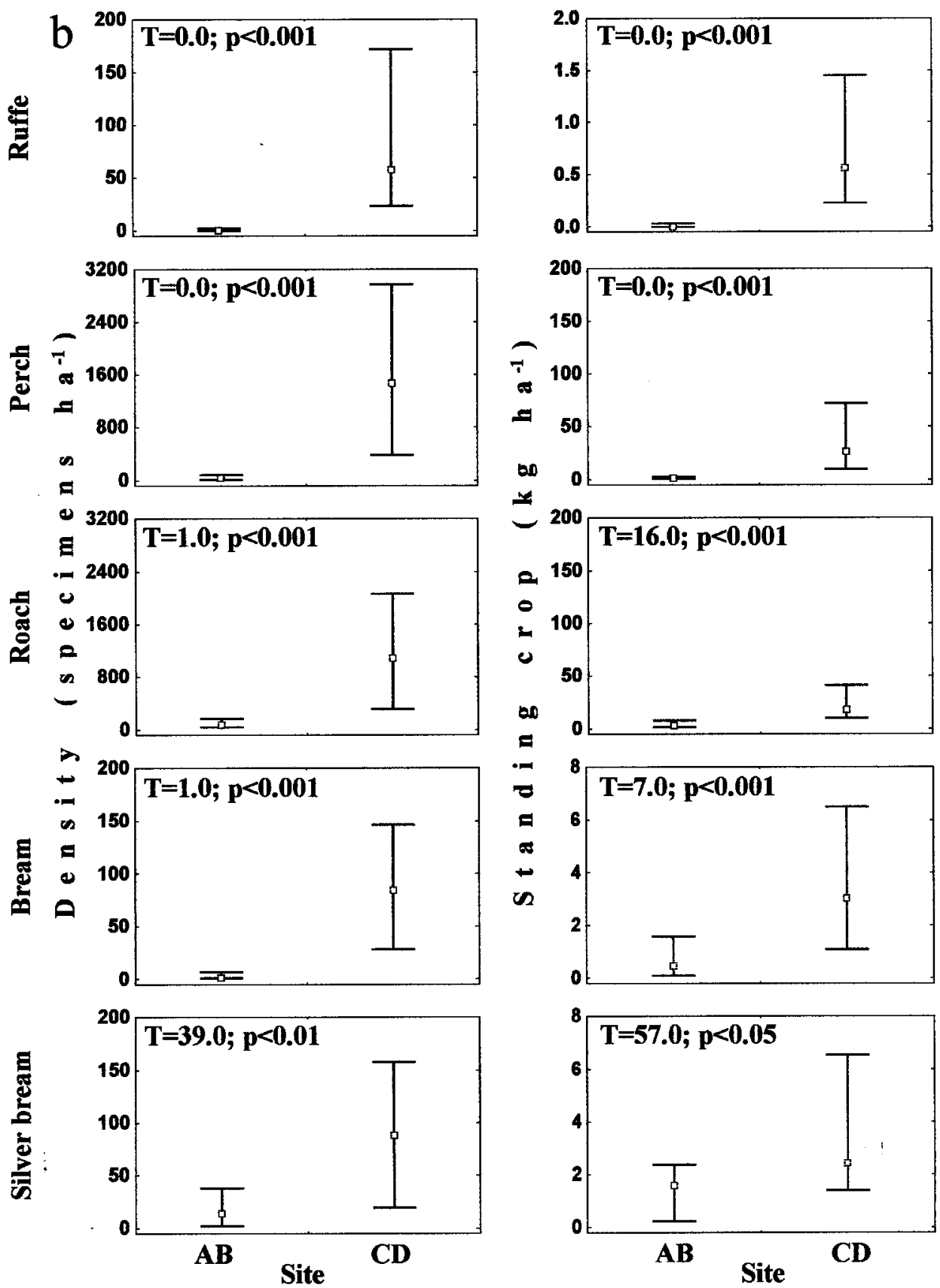

Fig. 4b. Spatial comparisons of densities and standing crops (median and quartiles) of (a) eel, burbot, wels, pike, zander, and (b) ruffe, perch, roach, bream and silver bream, between the backwater (AB) and tailwater (CD) in the Warta River for the post-impoundment period (Wilcoxon matched pairs test, $\mathrm{n}_{\mathrm{AB}}=21, \mathrm{n}_{\mathrm{CD}}=21$ ). 
Table 3. Temporal comparison of fish abundance and biomass per $1 \mathrm{~km}$ of river bank (medians or *if both medians equal 0 - upper quartiles) in the reference section of the Warta River (117-295 km), located upstream of AB (302 km). Mann-Whitney U test, $\mathrm{n}_{1986}=21$, $\mathrm{n}_{1998}=19$. Sig. level: Significance level. Based on Przybylski et al. (1993) and Kruk et al. (2000).

\begin{tabular}{crrlrrr}
\hline & \multicolumn{3}{c}{ Abundance } & \multicolumn{3}{c}{ Biomass (g) } \\
\cline { 2 - 7 } Species & 1986 & 1998 & Sig. level & 1986 & 1998 & Sig. level \\
\hline Eel $^{*}$ & 2.5 & 0.0 & $\mathrm{p}<0.05$ & 2063 & 0 & $\mathrm{p}<0.05$ \\
Burbot $_{\text {Wels* }}^{*}$ & 3.8 & 4.0 & & 475 & 360 & \\
Pike & 0.0 & 0.0 & 0 & 0 & \\
Zander* & 17.5 & 14.0 & & 4038 & 4517 & \\
Ruffe $^{*}$ & 1.3 & 0.0 & & 425 & 0 & \\
Perch & 0.0 & 0.0 & & 0 & 0 & \\
Roach & 6.3 & 26.0 & $p<0.01$ & 494 & 960 & \\
Bream & 99.1 & 144.0 & & 6985 & 4100 & \\
Silver bream & 1.3 & 0.0 & 88 & 0 & \\
\hline
\end{tabular}

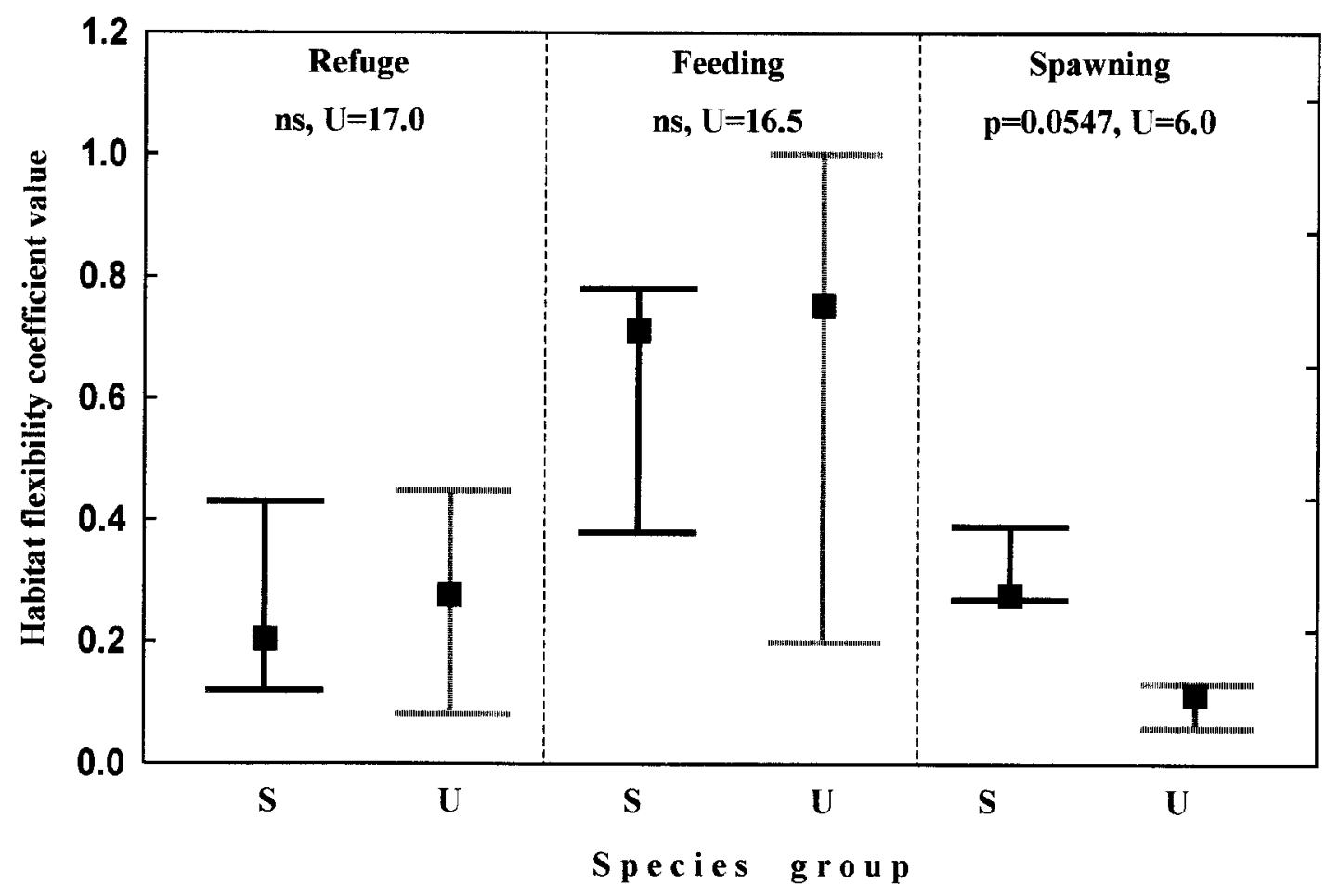

Fig. 5. Coefficients of habitat flexibility (according to Grandmottet, 1983) for species increasing (successful: S, solid line) and decreasing (unsuccessful: $U$, dotted line) in numbers in the post-impoundment period $\left(\mathrm{n}_{\mathrm{S}}=6, \mathrm{n}_{\mathrm{U}}=6\right.$ ). Explanations: point median, whiskers - quartiles. 
b). In spatial comparison (Fig. 4a, b) for all species, apart from the migratory eel, the situation after impoundment at $A B$ is very different from $C D$, however resembles very much the state recorded in the preimpoundment period at CD (Fig. 2a, b, 3a, b) which again suggests that the habitats have been less modified upstream of the dam.

The observation that eel have become less abundant upstream of the reservoir leads to the conclusion that this species suffers severely from the lack of river continuity. It previously migrated to the upstream basin of the Warta River (Penczak 1969), but the dam, without a fish pass, now prevents this. Apart from this obvious dam effect on migratory species, a decrease in eel numbers can also result from both limited recruitment (Lobón-Cerviá 1999) and stocking of eels (Bartel 1997). Till the eighties, eel larvae were stocked in Polish inland waters permanently. Now eel larvae rarely enter estuaries of Polish rivers (Backiel 1985) and governmental institutions have financial problems in purchasing juveniles for stocking because of very high prices.

Burbot and wels are becoming extirpated as a result of impoundment and/or accompanying impacts. Out of the latter, observed ecotone destruction may be of greatest importance, because burbot has a low tolerance to habitat structure alternations. Experiments demonstrate that juvenile burbot growth rates are significantly lower if preferred substratum is unavailable as inadequate shelter causes a high level of physiological stress, affecting somatic growth (Fischer 2000). High short-term flow variation and poaching when the river bed is uncovered can extirpate this species. In our opinion, the same factors may have eliminated wels, which prefer sites with hiding places and slow water velocity (Horoszewicz 1971).

Similarly, pike decreased in number in the tailwater because of permanent manipulation of the water flow by the hydropower plant (Penczak et al. 1998), which led to seasonal reduction of submerged macrophytes (Grzybkowska \& Dukowska 2001). Moreover, its young-of-the-year (YOY), which feed on macroinvertebrates, may have been out-competed for food by the YOY perch and roach (van Densen 1994), whose demographic explosions were observed at CD (Penczak 1994, 1999).

Other species (zander, ruffe, perch, roach, bream and silver bream) increased their populations in the postimpoundment period at CD (Fig. 2a, b). In most cases, the increase in numbers was proportionally higher than the increase in biomass, which may result from washing YOY cohorts from the reservoir down to tailwater, reported by Penczak (1994).
The two most abundant species at CD, eurytopic perch and roach, compose about $80 \%$ of all individuals captured in the post-impoundment period. Both species are characteristic of degraded and habitat-uniformed waters (Oberdorff \& Hughes 1992, Schiemer \& Wieser 1992, Wolter \& Vilcinskas 1997, Penczak et al. 2002). Their high dominance prevents high biological diversity. The latter assures natural stability and resistance to human impacts (Wootton 1990). They are also supposed to outcompete obligatory riverine fish (Degerman \& Sers 1994). This is why the increase in some species after impoundment definitely is not ecologically satisfactory.

The changes in ichthyofauna are a consequence of the dam construction, which is clearly visible when comparing them to the data from the reference $\mathrm{Wa} \mathrm{r}$ a section. Changes in facultative riverine species, recorded downstream of the Jeziorsko reservoir, were much greater than fluctuations observed in the slightly human-modified upper Warta section (table 3). Even the fourfold increase in perch density in the reference section (the biggest change observed there) was small in comparison with the over 100 fold increase at CD (Fig. $3 b)$. Nevertheless, the degree of decrease in eel population was similar which points out that for migratory fish the destructive effect of dams is not limited to downstream located river stretches only.

Of the flexibility coefficients for different habitat elements (table 2) only the coefficient relating to spawning differed between the two groups of species (successful/unsuccessful at CD after impoundment) (Fig. 5). The distant interquartile ranges testify to the critical role of spawning flexibility in a human-modified environment. Species able to complete their reproductive cycle in the reservoir prosper, supported by stocking activity. Others, less adapted to impoundment-related changes, rapidly or gradually decrease in numbers, making increase in flexible spawners, meeting less competitive resistance, much easier.

It is worth mentioning that much stronger angling pressure was recorded at CD because of higher fish abundance (Fig. 2a, b) and wing dikes making angling easier. While single anglers were fishing at $\mathrm{AB}$, tens of them were observed at $\mathrm{CD}$. Their number was highest in autumn and winter when the reservoir was covered with ice in contrast to the river. A study conducted in 1997-98 (Penczak et al. 1999) revealed that at CD they caught mainly perch $(71.6 \%)$ and additionally roach $(9.3 \%)$, ruffe $(8.3 \%)$, bream $(4.0 \%)$ and silver bream $(2.1 \%)$. The percentage of other species was $<2 \%$. Out of reophils sporadically dace $(0.2 \%)$ and chub 
$(0.1 \%)$ were angled. Thus, the angling pressure is focused on the most common species (Fig. 2b) and does not seem to be selective or influencing fish community structure. At CD also poaching was observed because of complete closing of sluices leading to exposure of up to $80 \%$ of river bottom. This allowed for catching fish trapped in pools with baskets and nets (Penczak et. al. 1998). However, the extend and selectivity of this phenomenon is not known.

\section{Acknowledgements}

We are indebted to Henryk Koszalinski, Lidia Marszal, Andrzej Zaczynski, Joanna Kostrzewa and Krzysztof Tloczek for field assistance during different phases of the study. We thank two anonymous reviewers for English improvement and valuable suggestions regarding the manuscript. The field research was supported by the Polish Anglers Association.

\section{References}

Adámek Z., Jirásek J., Pravda D., Sukop I., Hetesa J., Provázek R. \& Skrabánek A. 1985. - The food biology and biological value of roach (Rutilus rutilus) in the Musovská reservoir. Zivoc. Vyr., 10, 901-910.

Backiel T. 1985. - Fall of migratory fish populations and changes in commercial fisheries in impounded rivers in Poland. Pages 2841 in Alabaster J.S. (ed.). Habitat Modification and Fre s $h w$ a te $r$ Fisheries. Proceedings of a Symposium of the European Inland Fisheries Advisory Commission. Butterworths, FAO, London.

Bartel R. 1997. - Jak zarybiamy i czy tak dalej mozna? [What do we stock with and is it correct?]. Pages 11-28 in Backiel T. (ed.). Wedkarstwo w ochronie wód i ry b o s t a nó w. Materialy $k$ o $n$ fe rencyjne [Angling for water and fish communities pro te $c$ tion, Conf. Proceed.]. The Polish Anglers Association Publishers, Warsaw.

Degerman E. \& Sers B. 1994. - The effect of lakes on the stream fish fauna. Ecol. Freshw. Fish, 3, 116-122.

Erman D.C. 1986. — Long-term structure of fish populations in Sagehen Creek, California. T. Am. Fish. Soc., 115, 682-692.

Fischer P. 2000. - Test of competitive interactions for space between two benthic fish species, burbot Lota lota, and stone loach Barbatula barbatula. Environ. Biol. Fish., 58, 439-446.

Galicka W., Glowacki L. \& Penczak T. 1991. - Water pollution in the upper Warta River in 1985-1989. Acta Univ. Lodz., Folia lim nol., 5, 5-20.

Garcia de Jalon D., Sanches P. \& Camargo J.A. 1994. — Downstream effects of a new hydropower impoundment on macrophyte, macroinvertebrate and fish communities. Regul. Rivers: Res. Mgmt., 9, 253-261.

Glowacki L. \& Penczak T. 2000. — Impoundment impact on fish in the Warta River: species richness and sample size in the rarefaction method. J. Fish Biol., 57, 99-108.

Grandmottet J.P. 1983. — Principales exigences des téléostéens dulcicoles vis-à-vis de l'habitat aquatique. Annls scient. Univ. Besan çon, 4, 3-32.

Grzybkowska M. \& Dukowska M. 2001. - Communities of Chironomidae (Diptera) above and below a reservoir on a lowland river: long-term study. Annales Zoologici, 52, 235-247.

Holden P.B. 1979. - Ecology of riverine fishes in regulated streams with emphasis on the Colorado River. Pages 57-74 in Ward J.V. \& Stanford J.A. (eds). Ecology of Regulated Streams, Plenum Press, New York.
Horoszewicz L. 1971. — Sum [Wels]. PWRiL, Warsaw (in Polish).

Koryak M. \& Hoskin R. 1994. - Variables influencing the productivity and diversity of reservoir tailwater fisheries in the Upper Ohio River drainage basin. Pages 1-3 in P roceedings of $14^{\text {th }}$ In ternational Symposium of the North American Lake Management Society, 31 October - 5 November 1994 (NALMS). USA.

Kruk A., Penczak T., Galicka W., Koszalinski H., Tloczek K., Kostrzewa J. \& Marszal L. 2000. - Fish fauna of the Warta River. Annual of the Polish Anglers Association, 13, 35-67 (in Polish with English summary).

Kruk A., Penczak T. \& Przybylski. M. 2001. — Long term changes in the fish fauna of the upper Warta River. Annual of the Polish Anglers Association, 14/Suppl., 189-211 (in Polish with English summary).

Lobón-Cerviá J. 1999. — The decline of eel Anguilla anguilla (L.) in a river catchment of northern Spain (1986-1997). Further evidence for a critical status of eel in Iberian waters. A rch. Hydro biol., 2, 245-253.

Lusk S., Halacka K. \& Lusková V. 1995. — Influence of small hydroelectric power stations on fish communities in streams. Zivoc. Vyr., 40, 363-367.

Martinez P.J., Chart T.E., Trammell M.A., Wullschleger J.G. \& Bergersen E.P. 1994. - Fish species composition before and after construction of a main stem reservoir on the White River, Colorado. Environ. Biol. Fish., 40, 227-239.

Ney J.J. \& Mauney M. 1981. — Impact of a small impoundment on benthic macroinvertebrates and fish communities of a headwater stream in the Virginia Piedmont. Pages 102-112 in American Fi sheries Society, Warmwater Streams Symposium. Lawrence, Kansas, USA.

Northcote T.G., Arcifa M.S. \& Froehlich O. 1985. — Effect of impoudment and drawdown on the fish community of a South American river. Verh. Int. Ver. Limnol., 22, 2704-2711.

Oberdorff T. \& Hughes R.M. 1992. - Modification of an index of biotic integrity based on fish assemblages to characterize rivers of the Seine Basin, France. Hydrobiologia, 228, 117-130.

Penczak T. 1969. - The ichthyofauna of the rivers of the Lodz Upland and adjacent areas. Part I c. The hydrography and fishes of the Warta basin. Acta Hydrobiol, 11, 69-118 (in Polish with English summary).

Penczak T. 1992. — Fish production in the Warta River, Poland: a pre-impoundment study. Hydrobiologia, 237, 117-129.

Penczak T. 1994. - Fish Recruitment in the Warta River (19851992): Impoundment Study. Pol. Arch. Hydrobiol., 41, 293-300.

Penczak T. 1999. - Fish production and food consumption in the Warta River (Poland): continued post-impoundment study (19901994). Hydrobiologia , 416, 107-123.

Penczak T. in press. - Impact of impoundment (1985-2000) on fish assemblages in a large lowland river.

Penczak T. \& Kruk A. 2000. - Threatened obligatory riverine fishes in human-modified Polish rivers. Ecol. Fre s $h w$. Fish, 9, 109-117.

Penczak T. \& Romero T.E. 1990. - Accuracy of a modified catcheffort method for estimating fish density in large river (Warta River, Poland). Pages 191-196 in Cowx, I.G. (ed.). Developments in Electric Fishing. Fishing News Books, Oxford.

Penczak T., Czernik K. \& Koszalinski H. 1999. - Anglers' catches at the tailwater of the Warta River. Annual of the Polish Anglers Association, 12, 95-104 (in Polish with English summary).

Penczak T., Galicka W., Glowacki L. \& Koszalinski H. 1994. Fish stocks in the Warta River: continued post-impoundment study (1990-1992). Pol. Arch. Hydrobiol., 41, 347-363.

Penczak T., Galicka W. \& Koszalinski H. 1991. — Fish populations density and biomass in the Warta River: pre- and post-impoundment study. Acta Univ. Lodz., Folia limnol., 5, 59-77. 
Penczak T., Grzybkowska M. \& Galicka W. 1996. — Fish-benthos production relationships in an alluvial river: Allen paradox. Pol. Arch. Hydrobiol., 43, 257-271.

Penczak T., Glowacki L., Galicka W. \& Koszalinski H. 1998. — A long-term study (1985-1995) of fish populations in the impounded Warta River, Poland. Hydrobiologia, 368, 157-173.

Penczak T., O’Hara K. \& Kostrzewa J. 2002. — Fish bioenergetics model used for estimation of food consumption in a navigation canal with heavy traffic. Hydrobiologia, 479, 109-123.

Penczak T., Mahon R. \& Balon E.K. 1984. - The effect of an impoundment on the upstream and downstream fish taxocenes (Speed River, Ontario, Canada). Arch. Hydrobiol., 2, 200-207.

Petts G.E. 1984. — Impounded Rivers. John Wiley \& Sons, Chichester.

Ponton D. \& Vauchel P. 1998. — Immediate downstream effects of the Petit-Saut dam on young neotropical fish in a large tributary of the Sinnamary River (French Guiana, South America). Regul. Ri vers: Res. Mgmt., 14, 227-243.

Przybylski M., Frankiewicz P. \& Banbura J. 1993. - The fish fauna of the upper Warta River drainage basin. Annual of the Polish An glers Association, 6, 49-78 (in Polish with English summary).

Rosenberg D.M., Berkes F., Bodaly R.A., Hecky R.E., Kelly C.A. \& Rudd J.W.M. 1997. — Large-scale impacts of hydroelectric development. Environ. Rev., 5, 27-54.

Schiemer F. \& Waidbacher H. 1992. - Strategies of conservation of a Danubian fish fauna. Pages 365-382 in Boon P.J., Calow P. \& Petts G.E. (eds). River Conservation and Management. John Wiley \& Sons Ltd., London.

Schiemer F. \& Wieser W. 1992. — Epilogue: food and feeding ecomorphology, energy assimilation and conversion in cyprinids. En viron. Biol. Fish., 33, 223-227.
Stewart-Oaten A., Murdoch W.W. \& Parker K.R. 1986. — Environmental impact assessment: «pseudoreplication» in time? Ecology, 4, 929-940.

Tarczynska M., Nalecz-Jawecki G., Romanowska-Duda Z., Sawicki J., Beattie K.A., Codd G.A. \& Zalewski. M. 2001. — Tests for the toxicity assessment of cyanobacterial bloom samples. Environ. Toxicol., 16, 383-390

Travnichek V.H., Bain M.B. \& Maceina M.J. 1995. — Recovery of a warmwater fish assemblage after the initiation of a minimumflow release downstream from a hydroelectric dam. T. Am. Fish. Soc., 124 (6), 836-844.

van Densen W. L. T. 1994. - Predator enhancement in freshwater fish communities. Pages 102-117 in Cowx I.G. (ed.). Rehabilita tion of freshwater fisheries. Fishing News Books, Oxford.

Ward J.S. \& Stanford J.A. 1983. - The serial discontinuity concept of lotic ecosystems. Pages 29-42 in Fontaine T.D. \& Bartell S.M. (eds). Dynamics of lotic ecosystems. Ann. Arbor. Science, Collingwood.

Welcomme R.L. 1985. — River Fisheries. FAO Fish. Tech. Pap., $262,330 \mathrm{p}$

Wolter C. 2001. - Conservation of fish species diversity in navigable waterways. Landscape Urban Plan., 53, 135-144.

Wolter C. \& Vilcinskas A. 1997. — Perch (Perca fluviatilis) as an indicator species for structural degradation in regulated rivers and canals in the lowlands of Germany. Ecol. Fre $s$ w. Fish, 6, 174-181.

Wootton R.J. 1990. - Ecology of Teleost Fishes. Chapman and Hall, London, $404 \mathrm{p}$

Zar J.H. 1998. - Biostatistical analysis. Englewood Cliffs, New Jersey, Prentice-Hall.

Zippin C. 1956. - An evaluation of the removal method of estimating animal populations. Biometrics, 12, 163-169. 